\title{
The Influence of Knowledge Transfers on the Implementation of Enterprise Information Systems
}

\author{
Radhika Santhanam ${ }^{1}$, Sharath Sasidharan' ${ }^{1}$, Dan Brass ${ }^{1}$ and V. \\ Sambamurthy ${ }^{2}$ \\ 1 School of Management, Gatton College of Business and Economics, \\ University of Kentucky Lexington, KY-40506 \\ 2 Department of Accounting and Information Systems, Eli Broad Graduate \\ School of Management, Michigan State University, East Lansing, MI -
} 48824

\begin{abstract}
Introduction The implementation of Enterprise Information Systems is difficult and challenging. It requires that many users learn to use the new system and coordinate their work. The goal of this study is to understand the relationship between the extent of user learning via social means and its impact on the implementation success.
\end{abstract}

\section{Introduction}

Many organizations including public universities are implementing large Enterprise Information Systems using software such as SAP, PeopleSoft, etc [1, 2]. Some of these such as Enterprise Resource Planning Systems (ERP) are implemented to streamline operational processes, improve business performance, and facilitate information delivery methods in organizations. Despite these benefits from implementing ERP systems, reports list many problems faced during the implementation of these systems, that some of these have even been labeled as failures [3-7] Some of the more high profile organizations that have faced problems with enterprise system implementation include Hewlett Packard, Boeing, and Siemens [8-10]. Some large public Universities have implemented these systems and have seen its share of difficulties $[1,2]$. The costs of implementing ERP systems run into millions of dollars, and failure to properly implement the system can lead an organization into financial ruin [11-13]. Hence, researchers are interested in

Please use the following format when citing this chapter:

Santhanam, R., Sasidharan, S., Brass, D., Sambamurthy, V., 2006, in International 
understanding the various factors that could promote the successful implementation of these enterprise information systems.

When compared to smaller information systems used by single users, the diversity and the large number of users who have to adapt and learn to use a new enterprise information system add many complexities to the implementation process. Furthermore, users' tasks tend to be interdependent in that a user cannot work solely on their task, but may have to rely on the task results of other users. Groups of users have to learn, assimilate the new system, and use it to complete their interdependent tasks. Cases studies suggest that some groups of users (business units), and organizations seem to easily adapt to the new system and quickly reengineer business processes, while others face a more difficult time. Prior findings suggest that the implementation of these large integrated systems necessitate a substantial amount of knowledge transfers to occur among users of the system, sometimes referred to as social learning. The nature and extent of these knowledge transfers are expected have a substantial impact on the successful implementation of systems $[14,15]$. We therefore propose that if users in an unit are able to easily transfer knowledge and learn about the system, there is a greater likelihood that the implementation will be more successful in that unit.

Using Social Network Theory as our foundation, we test our ideas on an ERP system being implemented across many different units of our University $[16,17]$. We believe that organizational units characterized by close, diverse and dense ties among its employees will have relatively rapid and efficient knowledge transfers that serve to lower knowledge barriers and facilitate user learning; hence, we can expect a more successful implementation of the system. On the other hand, in organizational units with sparse, infrequent ties, knowledge transfers will tend to be fragmented leading to a slowing of the implementation process. We have developed multidimensional measures to gauge ERP success. We intend to determine the level of knowledge transfers occurring in a unit and determine its influence on these success measures.

We are collecting data from over thousand users of the ERP system that is being implemented at our University. We plan to collect data over three time periods, before the system is implemented to serve as a baseline measure, immediately after the system is implemented, and finally, we will collect data when the system is fully operational and in routine use. In the future, spending on EIS such as ERP systems, are predicted to increase even further, it is very critical to identify factors that can facilitate the successful implementation of these systems [9, 13, and 18]. We believe our empirical study can make a contribution by identifying the role of social knowledge transfers on the successful implementation of EIS and provide information for researchers and practioners to build upon.

\section{References}

1. F. F. Nah, J. L. Lau, and J. Kuang, Critical Factors for Successful Implementation of Enterprise Systems, Business Process Management Journal 7 (3), 285-296 (2001). 
Intormation systems

2. D. Robey and M. Boudreau, Learning to Implement Enterprise Systems: An Exploratory Study of the Dialectics of Change, Journal of Management Information 19 (1) 17-46 (2002).

3. P. Bingi, M. K. Sharma, and J. K. Godla, J. K., Critical Issues Affecting an ERP Implementation, Information Systems Management 16 (3), 7-14 (1999).

4. M. L. Markus and C. Tanis, The Enterprise System Experience: From Adoption to Success, in: Framing the Domains of IT Management: Projecting the Future through the Past, edited by R. W. Zmud (Pinnaflex Educational Resources Inc., Cincinnati, 2000).

5. I. J. Chen, Planning for ERP Systems: Analysis and Future Trend, Business Process Management Journal 7 (5) 374-386 (2001).

6. V. A. Mabert and M. A. Venkataramanan, Enterprise Resource Planning: Managing the Implementation Process, European Journal of Operational Research 146 (2), 302-314 (2003).

7. K. Hong and Y. Kim, The Critical Success Factors for ERP Implementation: An Organizational Fit Perspective, Information and Management 40 (1), 25-40 (2002).

8. M. L. Songini (2005a) Hewlett-Packard Company Facing Problems, Computerworld, http://www.computerworld.com/softwaretopics/erp/story/0.10801,100366,00.html?SKC=erp100366, last accessed, Feb 20, 2006.

9. M. L. Songini (2005b) Bungled ERP Installation Whacks Asyst, Computerworld, $\mathrm{http} / / / \mathrm{www} . c 0 m p u t e r w o r l d . c o m /$ softwaretopics/erp/story/0,10801,98815,00.html, last accessed Feb 20, 2006.

10. B. Seidel and C. Stedman, Siemens Cuts PeopleSoft Loose for SAP, Computerworld. 32 (40), 53-54 (1998).

11. B. Wallace, Now It's Cost-Cutting Time, Computerworld. 3, (1998).

12. K. Kumar and J. V. Hillegersberg, ERP Experiences and Evolution, Communications of the ACM 43 (4) 23-26 (2000).

13. E. Chabrow, Fed ERP Spending to Jump (2004) http://www.informationweek.com/showArticle.jhtml?articleID=29116654, last accessed Feb 20, 2006.

14. S. D. N. Cook and J. S. Brown, Bridging Epistemologies: The Generative Dance between Organizational Knowledge and Organizational Knowing, Organization Science 10(4), 381400 (1999).

15. D. Kang and R. Santhanam, A Longitudinal Field Study of Training Practices in a Collaborative Application Environment, Journal of Management Information System 20 (3), 257-281 (2003).

16. D. J. Brass, A Social Network Perspective on Human Resources Management, in: Research in Personnel and Human Resources Management, edited by G. Ferris (JAI Press, Greenwich, CT, 1995), 13, pp. 39-79.

17. M. E. Burkhardt and D. J. Brass, Changing Patterns or Patterns of Change: The Effects of a Change in Technology on Social Network Structure and Power, Administrative Science Quarterly 35, 104-107 (1990).

18. T. L. Legate, The Role of Organizational Factors in Realizing ERP Benefits, Information Systems Management 19 (4), 21-42 (2002). 